\title{
Peran Bifidobakteria dalam Pencegahan dan Pengobatan Alergi serta Gangguan Sistem Imun pada Anak
}

\author{
Ketut Dewi Kumara Wati, ${ }^{1}$ Budi Setiabudiawan ${ }^{2}$ \\ ${ }^{1}$ Departemen/KSM Ilmu Kesehatan Anak Fakultas Kedokteran Universitas Udayana/RSUP Sanglah,_Denpasar \\ ${ }^{2}$ Departemen/KSM Ilmu Kesehatan Anak Fakultas Kedokteran Universitas Padjadjaran/RSUP Hasan Sadikin, Bandung
}

Bifidobakteria berperan dalam dinamika maturasi sistem imun dan memiliki timeline yang terhubung dengan timeline sistem imun. Bifidobakteria membantu pembentukan sistem imun non-spesifik maupun spesifik, sedangkan sistem imun membantu pembentukan komposisi bifidobakteria. Bifidobakteria dapat berperan dalam sistem imun karena memiliki banyak enzim yang menunjang kolonisasi, mampu memelihara homeostasis mukosa intestinal, bekerjasama dengan mukus dan SIgA memerangkap patogen, membantu pembentukan SIgA dan IgM, serta meningkatkan survival koloni Treg. Secara klinis, penggunaan bifidobakterium tunggal maupun kombinasi bermanfaat untuk pencegahan dan pengobatan kasus alergi dan gangguan sistem imun. Pemberian bifidobakteria pada dosis $10^{9}$ colony forming unit satu hingga dua bulan sebelum kelahiran dilanjutkan pemberian pada bayi selama 6 bulan menurunkan kejadian dermatitis atopik. Pemberian bifidobakteria pada bayi prematur memperbaiki profil kolonisasi bifidobakteria, menurunkan kejadian, dan keparahan nerotizing enterocolitis. Pemberian bifidobakteria memperbaiki kualitas hidup rinitis alergi musiman dan asma intermiten, menurunkan skor dermatitis (SCORAD) dan penggunaan steroid pada dermatitis atopik, serta membantu menurunkan berulangnya infeksi saluran nafas pada anak. Sari Pediatri 2021;22(6):394-400

Kata kunci: bifidobakteria, sistem imun, maturasi, alergi, necrotizing enterocolitis, infeksi

\section{The Role of Bifidobacteria in The Prevention and Treatment of Allergies and Immune System Disorders in Children}

Ketut Dewi Kumara Wati, ${ }^{1}$ Budi Setiabudiawan ${ }^{2}$

Bifidobacteria play a role in the dynamics of the immune system maturation and have a linked timeline to the immune system. Bifidobacteria help the formation of nonspecific and specific immune systems while the immune system helps to shape the composition of bifidobacteria. Bifidobacteria have ability to play a role in the immune system due to enzyme properties that support colonization, can maintain intestinal mucosal homeostasis, cooperate with mucus and SIgA to trap pathogens, help the formation of SIgA and IgM, as well as increase Treg colonies survival. Bifidobacterium alone or in combination is useful for the prevention and treatment of allergic disease and immune system disorders. Administration of bifidobacteria at a dose of $10^{9}$ colony-forming units one to two months before delivery followed by the administration to infants for 6 months reduced the incidence of atopic dermatitis. Administration of bifidobacteria in premature infants improves the profile of bifidobacteria colonization, decreases the incidence and severity of necrotizing enterocolitis. Administration of bifidobacteria improves quality of life for seasonal allergic rhinitis and intermittent asthma, reduces SCORAD and steroid use in atopic dermatitis, as well as reduces recurrence of respiratory tract infections in children. Sari Pediatri 2021;22(6):394-400

Keywords: bifidobacteria, immune system, maturation, allergy, necrotizing enterocolitis, infection

Alamat korespondensi: Budi Setiabudiawan, Departemen/KSM Ilmu Kesehatan Anak Fakultas Kedokteran Universitas Padjadjaran/RSUP Hasan Sadikin, Bandung. Email: setiabudiawan@yahoo.com 
$\mathrm{P}$ eran bifidobakteria pada alergi banyak diminati setelah Kalliomaki $\mathrm{dkk}^{1}$ menemukan risiko sensitisasi alergi di usia 1 tahun berasosiasi dengan rendahnya bifidobakteria pada usia 3 minggu. He $\mathrm{dkk}^{2}$ selanjutnya mendapatkan perbedaan komposisi bifidobakteria antara anak dengan alergi dan anak sehat. Anak dengan alergi memiliki komposisi bifidobakteria serupa orang dewasa yang didominasi $B$. adolescentis, sedangkan komposisi bifidobakteria anak sehat didominasi $B$. bifidum. Bifidobakteria pada anak sehat melekat pada mukus intestinal lebih kuat dibandingkan anak dengan alergi. Hal tersebut menunjukkan korelasi komposisi bifidobakteria dengan penyakit alergi dan peran bifidobakteria dalam menjaga homeostasis sistem imun. Bagaimana bifidobakteria berperan dalam sistem imun diterangkan oleh kolaborasi sistem imun dan bifidobakteria sejak awal kehidupan.

\section{Timeline kolonisasi mikrobiota saluran cerna dengan pembentukan sistem imun anak pada usia dini}

Kadar progesteron ibu meningkat pesat pada kehamilan trimester akhir sehingga terjadi kolonisasi mikrobiota di jalan lahir terutama spesies bifidobakteria. ${ }^{3}$ Kolonisasi bifidobakteria juga terjadi intrauterin dan terdeteksi di plasenta, cairan amnion, dan mekonium yang merupakan fenomena fisiologis. ${ }^{4}$ Bifidobakteria, terutama $B$. infantis, $B$. longum, dan $B$. breve $e^{4}$ mulai teridentifikasi pada bayi berusia 2 hingga 4 hari. ${ }^{5,6}$ Koloni $B$. infantis bayi yang mendapat ASI mencapai 80-90\%, sedangkan bayi prematur dan yang mendapat susu formula memiliki koloni bifidobakteria lebih sedikit. ${ }^{7}$ Kolonisasi bifidobakteria meningkat setelah penyapihan hingga pubertas, tetapi koloni $B$. infantis dan $B$. longum berkurang karena transformasi menjadi pencerna tumbuhan dan musin. ${ }^{7,8}$ Bifidobakteria mencakup 50\% koloni mikrobiota pada masa remaja hingga dewasa, tetapi didominasi $B$. adolescentis. Koloni bifidobakteria pada masa dewasa hanya 3-6\% yang kemudian turun pada usia lanjut sejalan dengan berkurangnya koloni total. ${ }^{9}$

Sistem imun berevolusi dan menjalani maturasi bertahap setelah kelahiran melalui masa anak, pubertas, hingga dewasa. Sistem imun nonspesifik awalnya memiliki lapisan mukus tipis, sedikit glikosilasi, jarak epitel renggang, $\mathrm{pH}$ gaster tinggi, serta Peyer's patches yang jarang dan belum dipadati sel. Granulosit sedikit menghasilkan protease dan jarang mengekspresikan L-selektin. Kapasitas antigen presenting cell (APC) untuk endositosis, fagositosis, dan produksi sitokin terbatas. ${ }^{10,11}$

Sistem imunitas spesifik fetal dan bayi baru lahir teredam karena toleran terhadap antigen ibu. Sel T condong ke Th2 karena belum menghasilkan sitokin Th1. Sel T sitotoksik belum aktif, tetapi banyak terdapat

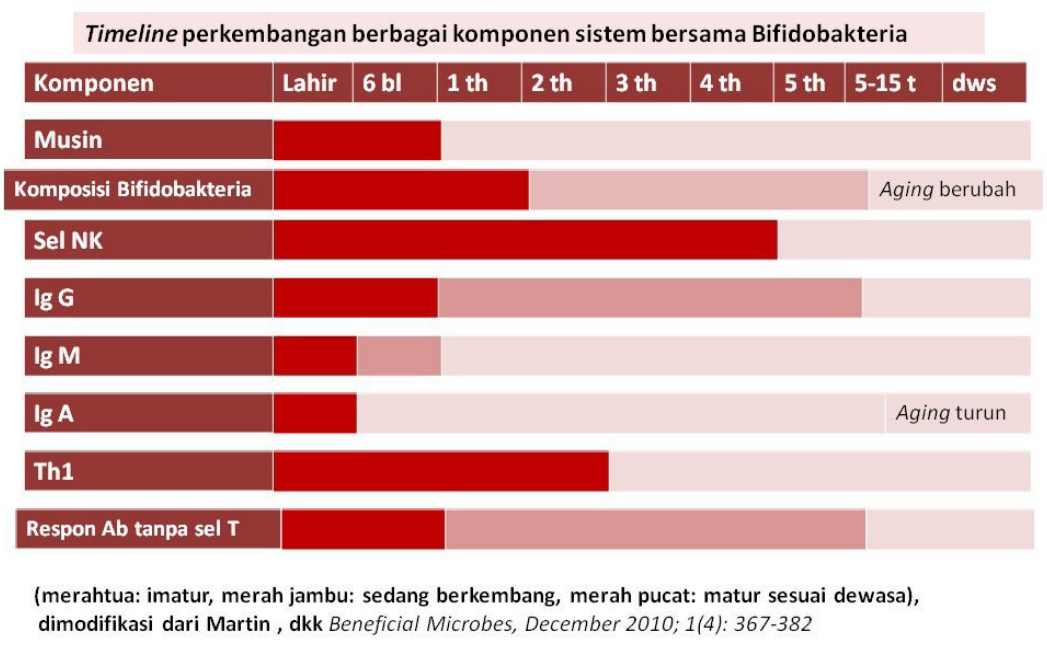

Gambar 1. Timeline antara perkembangan sistem imun dan bifidobakteria Dimodifikasi dalam Bahasa Indonesia dari Martin, dkk. ${ }^{10}$ 
T regulator (Treg). Sel Treg menurun tetapi Th1, Th17, dan Th2 meningkat pada masa anak. Populasi sel B banyak pada bayi baru lahir, tetapi maturasi sel plasma belum lengkap. ${ }^{10}$ Sel B1, yakni limfosit B yang diproduksi di hepar pada masa fetal, umumnya berada di peritonium mengekspresikan IgM nonspesifik. Sel B2 merupakan sel B konvensional yang berasal dari sumsum tulang dan berada di sirkulasi kurang mampu membentuk antibodi karena class switching belum sempurna. ${ }^{11}$ Meski menghasilkan memori, kadar antibodi tetap rendah hingga usia anak. Kadar antibodi dewasa baru tercapai saat usia 10 tahun. ${ }^{10}$

Mikrobiota membantu maturasi barier mukus, menginduksi produksi IgA, membantu pembentukan Th17, Treg, dan memori. Sel memori terbentuk karena kemiripan sekuens mikrobiom dengan patogen tertentu. Mikrobiota membantu respons poten sel $\mathrm{T}$ dan sel B sehingga memori mampu bertahan, meskipun infeksi terjadi sekali. Memori dibentuk oleh sel B yang bermigrasi ke sumsum tulang, serta antigen partikel yang menetap di dalam lymphoid dendritic cell (DC) di limfonod. Sel B terus membelah diri dan membentuk antibodi akibat persistensi antigen mikrobiota. ${ }^{11}$ Saat usia bertambah, sel T dan B memori bertambah akibat infeksi dan vaksinasi. Perbandingan komposisi sel naif dan memori berubah akibat pajanan mikrobiom dan makanan. Involusi timus setelah usia 65 tahun menyebabkan jumlah sel berkurang dan respons terhadap antigen baru terbatas. ${ }^{11}$ Timeline kolonisasi mikrobiota serta maturasi sistem imun ditampilkan pada skema Gambar 1 yang dimodifikasi dari Martin dkk. ${ }^{10}$

\section{Peran bifidobakteria pada pembentu- kan sistem imun usia dini}

Bifidobakteria berperan pada sistem imun karena banyak memiliki enzim yang menunjang kolonisasi. Kolonisasi bifidobakteria di kanal vagina pada trimester ketiga kehamilan terjadi karena memiliki enzim hidroxysteroid dehidrogenase yang memetabolisme steroid. ${ }^{12}$ Bifidobakterium infantis memiliki banyak hidrolase sehingga menjadi pengkoloni paling awal dan terbanyak pada awal kehidupan ${ }^{13,4}$ Manusia sedikit memiliki hidrolase sehingga sebagian besar human milk oligosaccharide (HMO) pada air susu ibu (ASI) tidak dicerna dan tiba utuh di kolon. Human milk oligosaccharide pada ASI tidak nutritif bagi bayi, tetapi secara selektif memberi nutrisi pada bifidobakteria sehingga kolonisasi segera meningkat setelah kelahiran.,14-16 Bifidobakteria bertahan di mukosa intestinal karena terjaminnya $\mathrm{HMO}$ pada bayi yang mendapat ASI. ${ }^{17}$ Bifidobakterium longum dan $B$. breve memiliki banyak transporter sehingga dapat menggunakan hasil pencernaan spesies lain ${ }^{5}$ melalui bifidus shunt. ${ }^{8}$

Bifidobakteria memelihara homeostasis di mukosa intestinal karena tidak menembus mukus dalam. Bifidobakteria tidak menembus barier mukus padat ataupun epitel intestinal karena glikans HMO yang mirip dengan glikans epitel mengalihkan perlekatan mikroba. ${ }^{18,19}$ Mukus dalam adalah lapisan padat yang melekat erat pada epitel yang terus diregenerasi. Lapisan mukus luar adalah hasil konversi mukus dalam yang bersifat longgar karena protein MUC2 dikelilingi glikans yang merenggang bila menyerap air. ${ }^{9,20}$ Bifidobakteria mengikat protein inti musin MUC2 pada mukus luar sambil memfermentasi glikans luar lapisan mukus sehingga $\mathrm{pH}$ intestinal turun dan patogen tidak dapat hidup. Hasil fermentasi juga merupakan sumber energi epitel kolon. ${ }^{9}$ Bifidobakteria bekerjasama dengan Secretory IgA (SIgA) dan mukus memerangkap patogen dalam biofilm selanjutnya dieksresi oleh peristaltik. ${ }^{18}$

Peran bifidobakteria pada imunitas spesifik tampak pada loop of immune system. Sel dendritik, sel B, maupun sel $\mathrm{M}$ pada kubah epitel intestinal mengenali microbial associated molecular pattern (MAMP) bifidobakteria. Bifidobakteria melakukan cross-talk saat MAMP dikenali oleh pattern recognition receptor (PRR) pada sel dendritik. ${ }^{21}$ Cross talk menyebabkan class switch recombination (CSR) pada sel B1 sehingga memodulasi produksi IgA di isolated lymphoid follicle (ILF) tanpa bantuan sel $T^{22,23}$ Transportasi IgA dimer dilakukan secara transitosis pada epitel atau sel goblet. Polymeric immunoglobulin receptor ( $\mathrm{pIgR}$ ) membantu IgA dimer menjadi SIgA saat dilepas ke lumen. ${ }^{21,23}$ Bifidobakteria merangsang epitel menghasilkan $\mathrm{pIgR}$ sehingga meningkatkan transitosis IgA. ${ }^{21,23}$ Bifidobakteria berinteraksi dengan glikans antigen golongan darah $\mathrm{ABO}$ yang disekresi epitel sehingga membantu produksi IgM di Peyer's patches dengan bantuan sel T. ${ }^{24,25}$

Microbial associated molecular pattern seperti eksopolisakarida maupun pili dari Bifidobakterium longum dan $B$. Breve menginduksi pembentukan IL10. 26,27 Produk fermentasi berupa short chain fatty acid (SCFA), seperti butirat, asetat, propionat, dan laktat juga membantu survival koloni sel Treg. ${ }^{28,29}$ Gambar 


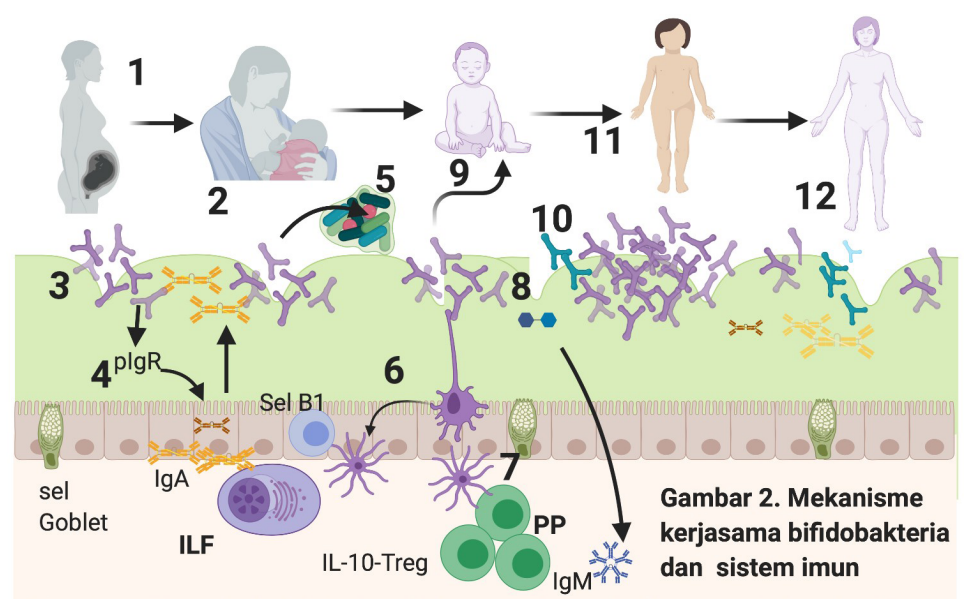

1. Terdeteksi intrauterin \& kolonisasi di kanal vagina pada trimester 3 kehamilan, 2. Memiliki glikosidase pencerna HMO ASI, 3. Adesi dan berikatan dengan protein musin MUC2, 4. Stimulasi epitel intestinal menghasilkan plgR untuk transitosis IgA, 5.Mencegah invasi patogen menembus mukus luar dengan membentuk biofilm bersama SIgA dan musin, 6.Dikenal oleh DC melalui MAMP lalu menginduksi sel B1 membentuk IgA di ILF, 7. Dipresentasikan oleh DC kepada sel T di PP meningkatkan populasi Treg, 8. Mencerna glikans ABO golongan darah yang disekresi epitel dan sel goblet, menginduksi pembentukan IgM oleh sel B2 di PP, 9. Inflamasi terkontrol di mukus luar, 10. Transformasi menjadi pencerna tumbuhan dan musin setelah penyapihan, 11 . Meningkat jumlahnya hingga pubertas, 12 . Menurun komposisinya saat dewasa dan turun jumlahnya saat usia tua. Keterangan: ILF: Isolated lymphoid follicle, $\mathrm{PP}=$ Peyer's patches, $\mathrm{plgR}=$ polymeric immunoglobulin receptor

Gambar 2. Mekanisme kerjasama bifidobakteria dengan sistem imun.

2 menunjukkan rangkuman mekanisme kerjasama bifidobakteria dan sistem imun.

\section{Mekanisme bifidobakteria dalam pencegahan dan pengobatan gangguan sistem imun pada anak}

Peningkatan kejadian alergi berasosiasi dengan peningkatan kelahiran melalui bedah Caesar. Kontak bayi dengan mikrobiota di jalan lahir tidak terjadi pada kelahiran melalui bedah Caesar, sehingga pola mikrobiota berubah, sistem imun condong kearah Th2, dan menimbulkan kejadian alergi. ${ }^{30}$ Penggunaan antibiotik dalam 2 tahun pertama kehidupan berasosiasi dengan hay fever, eksema, dan alergi makanan. ${ }^{31}$

Mikrobiota dan sistem imun mengalami disrupsi dalam keadan alergi. Anak dengan DA dan asma dilaporkan memiliki jumlah B. longum hanya $11 \%$, sedangkan anak sehat memiliki 33\% dari komposisi total. ${ }^{32}$ Fieten $\mathrm{dkk}^{33}$ menunjukkan anak dengan alergi makanan dan DA memiliki jumlah $B$. breve Iebih rendah dibanding kontrol. Penambahan bifidobakteria memperbaiki sistem imun ditinjau dari konsep disrupsi atau ketidakseimbangan mikrobiota pada alergi. ${ }^{34}$ Percobaan hewan dan klinis membuktikan penambahan bifidobakteria bermanfaat pada disfungsi sistem imun.

Tikus coba yang dipajan dengan tropomiosin udang disertai $B$. infantis menunjukkan penurunan IgE spesifik dan histamin. Penurunan IgE dan histamin lebih nyata bila $B$. infantis diberikan sebelum pajanan tropomiosin karena $B$. infantis memiliki kesempatan membantu maturasi sel dendritik dan sel Treg. ${ }^{35}$

\section{Pemberian bifidobakteria tunggal}

Penggunaan $B$. laktis pada anak dengan alergi makanan pada uji klinis tersamar ganda dengan dosis harian $10 \times 10^{6} / \mathrm{ml}$ selama 3 bulan mengurangi gejala alergi makanan dan IgE serum secara bermakna melalui Treg dan Th17. ${ }^{36}$ Suplementasi B. breve M-16V 5 x $10^{9}$ coloni forming unit $(\mathrm{cfu})$ setiap hari selama 3 bulan menunjukkan penurunan bermakna gejala DA seperti gatal dan kulit kering dibanding plasebo. ${ }^{37}$ 


\section{Pemberian bifidobakteria kombinasi}

Mekanisme cross feeding membentuk lebih banyak kolonisasi, sehingga pemberian kombinasi spesies atau subspesies meningkatkan efikasi. Suplementasi kombinasi B. breve $\mathrm{M} 16 \mathrm{~V}$ dan B. longum $\mathrm{Bb} 356$ dengan dosis $5 \times 10^{9} \mathrm{cfu} 2$ kali sehari pada wanita hamil sebulan sebelum melahirkan dilanjutkan pada bayi selama 6 bulan menyebabkan penurunan kejadian DA (OR 0,23, interval kepercayaan $[\mathrm{IK}] 95 \%: 0,0084-0,628) .{ }^{38}$

Pemberian kombinasi $B$ longum BB536 $\left(3 \times 10^{9} \mathrm{cfu}\right)$,

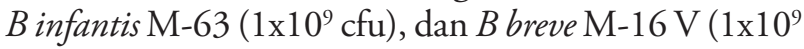
cfu) selama 8 minggu meningkatkan kualitas hidup pada rinitis alergi musiman dan asma intermiten. ${ }^{39}$ Systematic review penggunaan bifidobakteria tunggal atau kombinasi menurunkan DA, tetapi penggunaan bifidobakteria kombinasi lebih superior (RR 0,54 [IK 95\%: 0,43-0,68], $\mathrm{P}<0,00001) .{ }^{40}$

\section{Pemberian bifidobakteria dan spesies lain}

Penggunaan bifidobakteria dan laktobasilus bertujuan terapi terbukti menurunkan SCORAD secara bermakna setelah pemberian $10^{9} \mathrm{cfu}$ dua kali sehari selama 12 minggu pada DA yang dimediasi IgE. ${ }^{41}$ Bayi yang menggunakan susu formula ditambah kombinasi $B$ infantis, B.bifidum dan L. helvetikus $6 \times 10^{9} \mathrm{cfu}$ menunjukkan kadar SIgA feses kelompok intervensi lebih tinggi dan lebih lama dibanding kontrol. ${ }^{42}$ Metaanalisis mendapatkan kombinasi bifidobakteria dan laktobasilus lebih superior dibanding bifidobakteria untuk menurunkan SCORAD. ${ }^{43}$ Gerasimov $\mathrm{dkk}^{44}$ menggunakan kombinasi laktobasilus dan bifidobakteria selama 8 minggu pada anak prasekolah dengan DA menurunkan SCORAD, penggunaan steroid, CD4, IL-4, IL-5, dan IL-13.

\section{Pemberian bifidobakteria dan prebio- tik}

Prebiotik memberi nutrisi pada kolonisasi mikrobiota. Prebiotik yang sudah terbukti efikasinya adalah laktulosa, fruktooligosakarida (FOS) dan glukooligosakarida (GOS). Penggunaan B. breve dengan dosis $1,3 \times 10^{9}$ cfu/100ml dengan $90 \%$ scGOS dan $10 \%$ FOS yang diberikan secara on demand pada bayi usia kurang dari 7 bulan meningkatkan koloni bifidobakteria, menurunkan wheezy, dan IgE spesifik kucing. ${ }^{45}$

\section{Penggunaan bifidobakteria pada bayi prematur, infeksi dan inflamasi}

Kelahiran prematur berarti kolonisasi pada jalan lahir belum optimal. Penambahan B. infantis dibandingkan B. laktis menimbulkan kolonisasi sesuai dengan bayi aterm yang mendapat ASI. ${ }^{46} \mathrm{Li} \mathrm{dkk}$ (disitasi dari Wong $\mathrm{dkk}^{47}$ ) melaporkan suplementasi 4 jam sejak lahir menghasilkan kolonisasi lebih baik dibanding setelah 24 jam. Bayi prematur $<32$ minggu atau dengan berat lahir $<1500$ gram yang mendapat kombinasi $10^{9} \mathrm{~L}$. acidofilus dan $10^{9}$ B. bifidum selama 4-6 minggu mengalami penurunan kejadian necrotizing enterocolitis (NEC) dan beratnya NEC dibanding kontrol. ${ }^{48}$

Terdapat koneksi mukosa intestinal dengan organ lain sehingga inflamasi saluran nafas dapat menandakan disbiosis intestinal. Pemberian B. longum $1 \times 10^{9} \mathrm{cfu}$ pada anak pra-sekolah selama 10 bulan menurunkan nyeri tenggorok, batuk, ingus encer, dan durasi demam serta kekerapan infeksi saluran nafas. ${ }^{49}$

\section{Keamanan}

Bifidobacteria breve M16V mendapatkans sertifikat generally recognized as safe (GRAS) dari food drug administration (FDA) Amerika dan Cina. ${ }^{47}$

\section{Kesimpulan}

Bifidobakteria membantu maturasi sistem imun nonspesifik dan spesifik sedangkan sistem imun membantu pembentukan komposisi bifidobakteria. Penggunaan bifidobakteria bermanfaat pada pencegahan dan pengobatan kasus alergi serta gangguan sistem imun. Penambahan bifidobakteria tunggal atau kombinasi menurunkan kasus DA bila diberikan pada ibu sejak kehamilan dilanjutkan pada bayi. Pemberian bifidobakteria pada anak menurunkan SCORAD, memperbaiki kualitas hidup rinitis alergi musiman dan 
asma intermiten, memperbaiki komposisi bifidobakteria bayi prematur, menurunkan kejadian serta keparahan NEC, dan mengurangi berulangnya infeksi saluran nafas.

\section{Daftar pustaka}

1. Kalliomäki M, Kirjavainen P, Eerola E, Kero P, Salminen S, Isolauri E. Distinct patterns of neonatal gut microflora in infants in whom atopy was and was not developing. J Allergy Clin Immunol 2001;107:129-34.

2. He F, Ouwehand AC, Isolauri E, Hashimoto H, Benno Y, Salminen S. Comparison of mucosal adhesion and species identification of bifidobacterium from healthy and allergic infants. FEMS Immunol Med Microbiol. 2001;30:43-7.

3. Nuriel-Ohayon M, Neuman H, Ziv O, dkk. Progesterone Increases Bifidobacterium Relative Abundance during Late Pregnancy. Cell Rep 2019;27:730-6.e3.

4. Collado MC, Rautava S, Aakko J, Isolauri E, Salminen S. Human gut colonisation may be initiated in utero by distinct microbial communities in the placenta and amniotic fluid. Sci Rep 2016;6:1-13.

5. Wopereis H, Oozeer R, Knipping K, Belzer C, Knol J. The first thousand days - intestinal microbiology of early life: Establishing a symbiosis. Pediatr Allergy Immunol 2014;25:428-38.

6. O'Sullivan A, Farver M, Smilowitz JT. The Influence of early infant-feeding practices on the intestinal microbiome and body composition in infants. Nutr Metab Insights 2015;8:18-20.

7. O'Callaghan A, van Sinderen D. Bifidobacteria and their role as members of the human gut microbiota. Front Microbiol 2016;7:925.

8. Ruiz L, Gueimonde M, Couté Y, dkk. Evaluation of the ability of Bifidobacterium longum to metabolize human intestinal mucus. FEMS Microbiol Lett 2011;314:125-30.

9. Ruiz L, Delgado S, Ruas-Madiedo P, Sánchez B, Margolles A. Bifidobacteria and their molecular communication with the immune system. Front Microbiol 2017;8:1-9.

10. Martin R, Nauta AJ, Ben Amor K, Knippels LMJ, Knol J, Garssen J. Early life: Gut microbiota and immune development in infancy. Benef Microbes 2010;1:367-82.

11. Simon AK, Hollander GA, McMichael A. Evolution of the immune system in humans from infancy to old age. Proc R Soc B Biol Sci 2015;282:20143085.

12. Kisiela M, Skarka A, Ebert B, Maser E. Hydroxysteroid dehydrogenases in bacteria - A bioinformatic perspective. J Steroid Biochem Mol Biol 2012;129:31-46.

13. Underwood MA, German JB, Lebrilla CB, Mills DA. Bifidobacterium longum subspecies infantis: Champion colonizer of the infant gut. Pediatr Res 2015;77:229-35.

14. Kaoutari A El, Armougom F, Gordon JI, Raoult D, Henrissat B. The abundance and variety of carbohydrate-active enzymes in the human gut microbiota. Nat Rev Microbiol 2013;11:497-504.
15. Ballard O, Morrow AL. Human Milk Composition. Nutrients and Bioactive Factors. Pediatr Clin North Am 2013;60:49-74.

16. Zivkovic AM, German JB, Lebrilla CB, Mills DA. Human milk glycobiome and its impact on the infant gastrointestinal microbiota. Proc Natl Acad Sci U S A 2011;108:4653-8.

17. Rogier EW, Frantz AL, Bruno MEC, Kaetzel CS. Secretory $\operatorname{IgA}$ is concentrated in the outer layer of colonic mucus along with gut bacteria. Pathogens 2014;3:390-403.

18. Rogier EW, Frantz AL, Bruno MEC, dkk. Lessons from mother: Long-term impact of antibodies in breast milk on the gut microbiota and intestinal immune system of breastfed offspring. Gut Microbes 2015;5:663-8.

19. Mantis NJ, Forbes SJ. Secretory IgA: Arresting microbial pathogens at epithelial borders. Immunol Invest 2010;39:383-406.

20. Johansson MEV, Holmén Larsson JM, Hansson GC. The two mucus layers of colon are organized by the MUC2 mucin, whereas the outer layer is a legislator of host-microbial interactions. Proc Natl Acad Sci U S A 2011;108:4659-65.

21. Owen JL, Mohamadzadeh M. Microbial activation of gut dendritic cells and the control of mucosal immunity. J Interf Cytokine Res 2013;33:619-31.

22. Suzuki K, Kawamoto S, Maruya M, Fagarasan S. GALT. Organization and dynamics leading to IgA synthesis. Adv Immunol 2010;107:153-85.

23. Kaetzel CS. Cooperativity among secretory IgA, the polymeric immunoglobulin receptor, and the gut microbiota promotes host-microbial mutualism. Immunol Lett 2014;162:10-21.

24. Mäkivuokko H, Lahtinen SJ, Wacklin P, dkk. Association between the $\mathrm{ABO}$ blood group and the human intestinal microbiota composition. BMC Microbiol 2012;12:94.

25. Janzon A, Goodrich JK, Koren O, Waters JL, Ley RE. Interactions between the gut microbiome and mucosal immunoglobulins A, M, and G in the developing infant gut. mSystems 2019;4:1-17.

26. Altmann F, Kosma P, O'Callaghan A, dkk. Genome analysis and characterisation of the exopolysaccharide produced by bifidobacterium longum subsp. Longum $35624^{\mathrm{TM}}$. PLoS One 2016;11:1-23.

27. Turroni F, Serafini F, Ventura M. Role of sortase-dependent pili of Bifidobacterium bifidum PRL2010 in modulating bacterium - host interactions. Proc Natl Acad Sci. 2013;110:11151-6.

28. Turroni F, Milani C, Duranti S, dkk. Deciphering bifidobacterial-mediated metabolic interactions and their impact on gut microbiota by a multi-omics approach. ISME J 2016;10:1656-68.

29. Wang G, Huang S, Wang Y, dkk. Bridging intestinal immunity and gut microbiota by metabolites. Cell Mol Life Sci 2019;76:3917-37.

30. Sandall J, Tribe RM, Avery L, dkk. Short-term and longterm effects of caesarean section on the health of women and children. Lancet 2018;392:1349-57.

31. Ahmadizar F, Vijverberg SJH, Arets HGM, dkk. Early-life antibiotic exposure increases the risk of developing allergic symptoms later in life: A meta-analysis. Allergy Eur J Allergy Clin Immunol 2018;73:971-86. 
32. Akay HK, Bahar Tokman H, Hatipoglu N, dkk. The relationship between bifidobacteria and allergic asthma and/ or allergic dermatitis: A prospective study of 0-3 years-old children in Turkey. Anaerobe 2014;28:98-103.

33. Fieten KB, Totté JEE, Levin E, dkk. Fecal microbiome and food allergy in pediatric atopic dermatitis: A cross-sectional pilot study. Int Arch Allergy Immunol 2018;17:77-84.

34. Wang HT, Anvari S, Anagnostou K. The role of probiotics in preventing allergic disease. Children (Basel) 2019;6:24.

35. Fu L, Song J, Wang C, Fu S, Wang Y. Bifidobacterium infantis potentially alleviates shrimp tropomyosin-induced allergy by tolerogenic dendritic cell-dependent induction of regulatory $\mathrm{T}$ cells and alterations in gut microbiota. Front Immunol 2017;8:1-14.

36. Liu Q, Jing W, Wang W. Bifidobacterium lactis ameliorates the risk of food allergy in chinese children by affecting relative percentage of Treg and Th17 cells. Can J Infect Dis Med Microbiol 2018:2018:4561038.

37. Taniuchi S, Hattori H, Yamammoto, dkk. Administration of bifidobacterium to infants with atopic dermatitis: changes in fecal microflora and clinical symptoms. J Appl Res 2005;5:386-96.

38. Enomoto T, Sowa M, Nishimori K, dkk. Effects of bifidobacterial supplementation to pregnant women and infants in the prevention of allergy development in infants and on fecal microbiota. Allergol Int 2014;63:575-85.

39. Miraglia Del Giudice M, Indolfi C, Ciprandi G. Bifidobacterium mixture (B longum BB536, B infantis M-63, $\mathrm{B}$ breve $\mathrm{M}-16 \mathrm{~V}$ ) treatment in children with seasonal allergic rhinitis and intermittent asthma. Ital J Pediatr 2017;43:25.

40. Zuccotti G, Meneghin F, Aceti A, dkk. Probiotics for prevention of atopic diseases in infants: Systematic review and meta-analysis. Allergy 2015;70:1356-71.

41. Navarro-Lopez V, Ramirez-Bosca A, Ramon-Vidal D, dkk.
Effect of oral administration of a mixture of probiotic strains on SCORAD index and use of topical steroids in young patients with moderate atopic dermatitis a randomized clinical trial. JAMA Dermatol 2018;154:37-43.

42. Xiao L, Gong C, Ding Y, dkk. Probiotics maintain intestinal secretory immunoglobulin A levels in healthy formula-fed infants: A randomised, double-blind, placebo-controlled study. Benef Microbes 2019;10:729-39.

43. Kim SO, Ah YM, Yu YM, Choi KH, Shin WG, Lee JY. Effects of probiotics for the treatment of atopic dermatitis: A metaanalysis of randomized controlled trials. Ann Allergy, Asthma Immunol 2014;113:217-26.

44. Gerasimov SV, Vasjuta VV, Myhovych OO, Bondarchuk LI. Probiotic supplement reduces Atopic Dermatitis in preschool children: A randomized, double-blind, placebo-controlled, clinical trial. Am J Clin Dermatol 2010;11:351-61.

45. Van Der Aa LB, Heymans HS, Van Aalderen WM, dkk. Effect of a new synbiotic mixture on atopic dermatitis in infants: A randomized-controlled trial. Clin Exp Allergy 2010;40:795-804.

46. Underwood MA, Kalanetra KM, Bokulich NA, dkk. A comparison of two probiotic strains of bifidobacteria in premature infants. J Pediatr 2013;163:1585-91.e9.

47. Wong CB, Iwabuchi N, Xiao JZ. Exploring the science behind Bifidobacterium breve M-16V in infant health. Nutrients 2019;11:8

48. Meyer MP, Chow SSW, Alsweiler J, dkk. Probiotics for prevention of severe necrotizing enterocolitis: experience of New Zealand Neonatal Intensive Care Units. Front Pediatr 2020;8:119.

49. Lau ASY, Yanagisawa N, Hor YY, dkk. Bifidobacterium longum BB536 alleviated upper respiratory illnesses and modulated gut microbiota profiles in Malaysian pre-school children. Benef Microbes 2018;9:61-70. 